\title{
STRATEGI PEMANFAATAN MEDIA PEMBELAJARAN DALAM MENGATASI KESULITAN BELAJAR SISWA PADA MATA PELAJARAN EKONOMI DI SMA NEGERI 3 KOTA JAMBI
}

\author{
Redi Indra Yudha, M.Pd.E \\ Program Studi Pendidikan Ekonomi, FKIP UNBARI \\ E-mail : ilcapitanoredi@gmail.com
}

\begin{abstract}
This study aims to determine the strategy of utilizing learning media in overcoming student learning difficulties in economic subjects at SMA Negeri 3 Kota Jambi. The design of this study uses descriptive qualitative. Meanwhile, the technique in this study uses a purposive technique that is the determination of informants not based on guidelines or based on population representation, but based on the depth of information needed related to the research problem. The results showed that 1) The teacher has a variety of strategies and approaches used in conveying subject matter that does not depend on just one medium, and 2) Difficulties in student learning in economic subjects can be overcome by using a variety of media that can be used as intermediaries or sources for students in learning.
\end{abstract}

Keyword : Strategy, Utilization, Media, Learning Difficulties

\section{PENDAHULUAN}

Belajar merupakan aktivitas penting dalam kehidupan manusia, dan setiap individu akan mengalami berbagai macam pembelajaran dalam hidupnya. Setiap manusia pada umumnya dan siswa pada khususnya perlu proses pendewasaan, baik pendewasaan secara fisik maupun psikis atau kejiwaan. Pendewasaan pada diri seseorang terlebih pada diri seorang siswa tidak bisa sempurna tanpa didukung dengan berbagai aktivitas yang berasal dari pengalaman-pengalaman yang berupa pelatihan, pembelajaran, serta proses belajar. Artinya, belajar dan pembelajaran merupakan proses penting bagi siswa dalam interaksi belajarnya untuk menuju kedewasaan.

Guru memang bukan satu-satunya sumber belajar, walaupun tugas, peranan, dan fungsinya dalam proses belajar mengajar sangat penting. Apabila dilihat ke belakang dari sejarah perkembangan profesi guru, tugas mengajarnya sebenarnya adalah pelimpahan dari tugas orang tua karena tidak mampu lagi memberikan pengetahuan, keterampilan, dan sikap-sikap tertentu sesuai dengan perkembangan zaman saat ini. Oleh karena itu, dengan berkembangnya ilmu pengetahuan dan teknologi, dan perkembangan masyarakat serta budaya pada umumnya, berkembang pula tugas dan peranan guru, seiring dengan berkembangnya anak yang membutuhkan pendidikan.

Dalam melaksanakan kegiatan pembelajaran siswa cenderung menemukan berbagai kendala dan hambatan untuk dapat memahami materi pelajaran yang diberikan oleh guru yang bersangkutan. Hal ini 
dikarenakan, tidak semua siswa memiliki kecerdasan secara intelegensi maupun emosional yang sama satu dengan yang lainnya. Oleh karena itu, peran guru dalam pembelajaran sangat berperan penting dan diharapkan mampu mengatasi berbagai kendala dan hambatan tersebut, dimana dapat dilakukan dengan berbagai macam model pembelajaran maupun menggunakan media pembelajaran yang sesuai dengan materi pelajaran yang disampaikan.

Mengatasi kesulitan belajar sendiri sebenarnya sudah sering dilakukan guru dalam kegiatan belajar mengajar meski secara tidak langsung, akan tetapi hal tersebut malah membuat hampir setengah isi kelas tidak menyadari hal-hal kecil tersebut, seperti pemberian tugas oleh guru sehingga mampu mengulang kembali pelajaran di rumah, pemberian intruksi kepada siswa untuk bertanya apabila ada yang belum memahami materi yang disampaikan, dan lain sebagainya. Maka dari itu setidaknya penggunaan media pembelajaran dalam kegiatan belajar mengajar dapat menjadi alternatif dan langkah baru dalam mengatasi kesulitan belajar para siswanya.

Media pembelajaran secara lebih utuh dapat didefinisikan sebagai alat bantu berupa fisik maupun non fisik yang sengaja digunakan sebagai perantara antara guru dan siswa dalam memahami materi pembelajaran agar lebih efektif dan efisien. Sehingga materi pembelajaran lebih cepat diterima siswa dengan utuh serta menarik minat siswa untuk belajar lebih lanjut. Pendek kata, media merupakan alat bantu yang digunakan guru dengan desain yang disesuaikan untuk meningkatkan kualitas pembelajaran (Musfiqon, 2012:28). Sementara, Sadiman, dkk (2012:17-18), menjelaskan bahwa secara umum media pendidikan mempunyai kegunaan-kegunaan sebagai berikut:

1. Memperjelas penyajian pesan agar tidak terlalu bersifat verbalistis (dalam bentuk kata-kata tertulis atau lisan belaka).

2. Mengatasi keterbatasan ruang, waktu dan daya indera.

3. Penggunaan media pendidikan secara tepat dan bervariasi dapat mengatasi sikap pasif anak didik.

4. Dengan sifat yang unik pada tiap siswa ditambah lagi dengan lingkungan dan pengalaman yang berbeda, sedangkan kurikulum dan materi pendidikan ditentukan sama untuk setiap siswa, maka guru banyak mengalami kesulitan bilamana semuanya itu harus diatasi sendiri.

Hamdani (2011:17), mengemukakan "Kesulitan belajar merupakan suatu kondisi yang menunjuk pada sejumlah kelainan yang berpengaruh pada pengorganisasian, penyimpangan, pemahaman, dan penggunaan informasi secara verbal dan non verbal. Akibat dari keadaan ini individu yang mengalami kesulitan belajar mengalami kesulitan dalam mengoperasikan pikiran karena kondisi yang berkaitan dengan kesulitan belajar mempengaruhi fungsi intelektual secara 
umum”. Sementara, Rumini (2013:254), mengemukakan bahwa "Kesulitan belajar merupakan kondisi saat siswa mengalami hambatan-hambatan tertentu untuk mengikuti proses pembelajaran dan mencapai hasil belajar secara optimal”.

Menurut Aunurrahman (2016:178-196) bahwa faktor-faktor penyebab kesulitan belajar dapat digolongkan ke dalam dua golongan, yaitu: 1) Faktor intern (faktor dari dalam diri manusia itu sendiri) yang meliputi ciri khas/karakteristik siswa, sikap terhadap belajar, motivasi belajar, konsentrasi belajar, mengolah bahan belajar, menggali hasil belajar, rasa percaya diri, dan kebiasaan belajar; 2) Faktor ekstern (faktor dari luar manusia) meliputi faktor guru, lingkungan sosial (termasuk teman sebaya), kurikulum sekolah, dan sarana dan prasarana.

Dengan demikian, dapat disimpulkan bahwa tujuan pembelajaran itu sendiri adalah mengembangkan strategi dan teknologi yang lebih optimal dan maksimal dalam rangka menciptakan pemahaman, wawasan, pengetahuan, dan keterampilan siswa untuk menghadapi berbagai interaksi dalam melakukan aktivitas belajar pada setiap lingkungan belajar yang berbeda secara terus menerus. Oleh karena itu, pembelajaran harus mampu menjawab kebutuhan siswa untuk merencanakan kesiapan belajar, bagaimana membangun dorongan dalam diri sehingga mampu menimbulkan kontinuitas belajar yang lebih baik, dan membangun komunikasi pribadi yang efektif dengan orang tua, guru, masyarakat, maupun teman sebaya mereka.

Hal ini dikarenakan, seiring dengan kesiapan guru yang matang dalam penggunaan media sebagai pengganti materi yang bersifat verbal diharapkan mampu setidaknya membuat siswa aktif dan lebih berinteraksi secara intensif saat pembelajaran berlangsung. Pada akhrinya, hal tersebut kembali pada ungkapan bahwa seorang guru memiliki peran dan sebagai ujung tombak yang paling menentukan keberhasilan dan implementasi dalam dunia pendidikan pada setiap jenjangnya. Adapun kerangka berpikir dalam penelitian ini dapat dilihat pada gambar sebagai berikut:

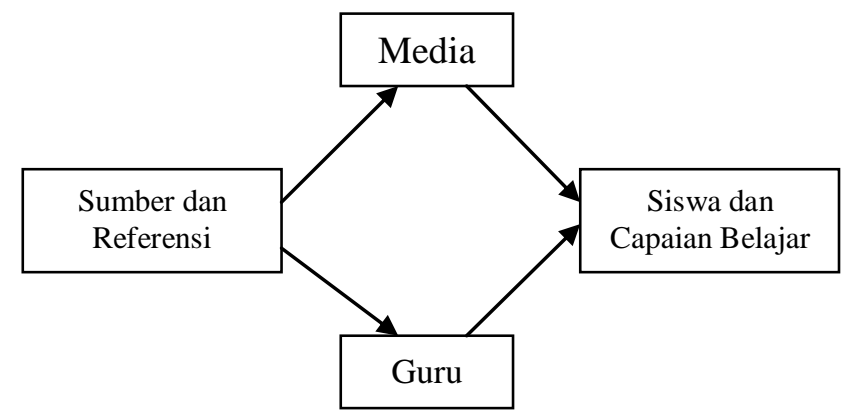

\section{Gambar 1 Kerangka Berpikir}

\section{METODOLOGI PENELITIAN}

Desain penelitian yang digunakan dalam penelitian ini adalah deskriptif kualitatif. Moleong (2017:5) menyatakan bahwa penelitian kualitatif adalah "Penelitian yang menggunakan latar alamiah, dengan maksud menafsirkan fenomena yang terjadi dan dilakukan dengan jalan melibatkan berbagai metode yang ada". Dari segi pengertian ini, para penulis masih tetap mempersoalkan latar alamiah dengan maksud agar hasilnya dapat 
digunakan untuk menafsirkan fenomena dan yang dimanfaatkan untuk penelitian kualitatif adalah berbagai macam metode penelitian. Dalam penelitian kualitatif metode yang biasanya dimanfaatkan adalah wawancara, pengamatan, dan pemanfaatan dokumen. Berdasarkan pengertian tersebut maka dalam penelitan ini peneliti bermaksud untuk menjelaskan dan menggambarkan secara mendalam terkait "strategi pemanfaatan media pembelajaran dalam mengatasi kesulitan belajar siswa pada mata pelajaran ekonomi di SMA Negeri 3 Kota Jambi”.

Moleong (2017:247) "Proses analisis data dimulai dengan menelaah seluruh data yang tersedia dari berbagai sumber, yaitu dari wawancara, pengamatan yang sudah dituliskan dalam catatan lapangan, dokumen pribadi, dokumen resmi, gambar, foto, dan sebagainya". Teknik pemeriksaan keabsahan data yang digunakan dalam penelitian ini adalah teknik Triangulasi. Menurut Moleong (2017:330) triangulasi adalah "Teknik pemeriksaan keabsahan data yang memanfaatkan sesuatu yang lain di luar data itu untuk keperluan pengecekan atau sebagai pembanding terhadap data itu". Empat macam triangulasi sebagai teknik pemeriksaan yang memanfaatkan penggunaan sumber, metode, penyidik dan teori (Moleong, 2017:330).

\section{HASIL DAN PEMBAHASAN}

Berdasarkan perolehan yang didapat baik dari hasil wawancara, observasi, dan perolehan data pendukung lain terkait Strategi
Pemanfaatan Media Pembelajaran Dalam Mengatasi Kesulitan Belajar Siswa pada mata pelajaran ekonomi Di SMA Negeri 3 Kota Jambi, dapat diketahui sebagai berikut:

\section{Hasil Penelitian}

\section{a. Memperjelas Penyajian Pesan Agar} Tidak Terlalu Bersifat Verbalistis (dalam Bentuk Kata-Kata Tertulis atau Lisan Belaka)

Penggunaan media dalam kegiatan belajar mengajar di kelas akan membantu para guru dalam menyampaikan materi pelajaran karena bahasa media akan lebih cepat dimengerti oleh setiap siswa. Maka, semakin berkembangnya teknologi yang pesat dan untuk menghindari siswa tergantung pada internet dalam mencari jawaban dan menyelesaikan tugas, guru harus memikirkan penggunaan media yang cocok dalam setiap menyampaikan materi. Meskipun tidak semua materi mampu untuk disampaikan dengan menggunakan media, seperti perhitungan rumus matematika dan pencatatan keuangan akuntansi. Hal ini dikarenakan, bahasa media adalah bahasa universal dan tidak bersifat verbal sehingga siswa dapat lebih cepat menerima materi pelajaran yang diberikan oleh guru.

Berdasarkan hasil wawancara dengan para guru di SMA Negeri 3 Kota Jambi, diperoleh kesimpulan bahwa tanpa adanya media yang digunakan dalam penyajian materi, cenderung kondisi kelas belum dapat dikontrol secara baik oleh guru 
dengan catatan bahwasanya "bahasa $L K S$ yang mudah dipahami saja belum tentu dapat dimengerti oleh siswa, bahkan tidak jarang dan tidak menutup kemungkinan siswa mengerjakan tugas LKS dengan cara menyontek teman mereka". Apabila diterapkan dengan penggunaan media pembelajaran secara wajib, para guru cenderung belum merasa siap dikarenakan harus menyesuaikan materi ajar dengan pilihan media yang akan digunakan nanti.

\section{b. Mengatasi Keterbatasan Ruang, Waktu dan Daya Indera}

Masing-masing siswa memiliki cara dan gaya belajar mereka sendiri dan hal tersebut sudah berlaku untuk dijadikan tugas bagi para guru selain mengajar sejak dulu. Ruang kelas merupakan sarana bagi para siswa untuk dapat belajar dengan kondisi dan situasi yang menyenangkan, aman, kondusif, dan lain sebagainya, terkecuali bagi sekolah alam yang baru dibangun setingkat Sekolah Dasar yang memiliki ruang tidak terbatas dan mampu menghadirkan pengetahuan dan pemahaman yang baru bagi para siswanya. Hal ini dikarenakan, belajar pada dasarnya upaya perubahan dari tidak tahu menjadi tahu, dimana hal tersebut dapat dilakukan dengan berbagai sumber-sumber referensi dan media informasi yang akurat terkait dengan materi pelajaran yang dipelajari oleh siswa.

Berdasarkan hasil wawancara dengan para guru di SMA Negeri 3 Kota Jambi, diperoleh kesimpulan bahwa tidak semua siswa akan terbiasa belajar dengan cara penggunaan media pembelajaran yang selalu sama, bahkan hal tersebut dapat menjadi catatan tambahan bagi para guru dalam menyampaikan materi pelajaran mereka di dalam kelas. Penggunaan media pembelajaran terhadap diri siswa memang sangat dibutuhkan dalam pengembangan kemampuan siswa dalam berpikir dan mengambil keputusan daripada harus membaca dan menelaah tulisan yang ada dibuku pelajaran maupun lks. Meskipun demikian, para guru lebih cenderung memberikan contoh-contoh yang lebih mudah dipahami oleh siswa daripada harus menyita waktu pelajaran dan waktu di luar sekolah hanya untuk memikirkan media apa yang akan digunakan dalam setiap menyampaikan materi pelajaran. Hal ini dikarenakan, tidak semua materi berisi informasi yang sama dari sebelumnya bahkan materi cenderung memiliki isi dan makna yang berkaitan satu sama lain dengan materi yang berikutnya.

\section{c. Penggunaan Media Pendidikan}

Secara Tepat dan Bervariasi Dapat

\section{Mengatasi Sikap Pasif Anak Didik}

Aktivitas pembelajaran yang dilakukan oleh siswa tidak hanya mengajarkan mereka tentang pengetahuan dan pemahaman tentang ilmu baru saja, melainkan memberikan kesempatan kepada siswa untuk dapat menunjukkan kemampuan mereka dalam bidang 
akademik pula. Interaksi-interaksi belajar juga tidak terbatas pada interaksi guru dengan siswa, namun interaksi siswa satu dengan yang lainnya juga dapat memberikan kesempatan kepada siswa untuk membangun sisi emosional mereka dalam mengikuti kegiatan belajar mengajar. Oleh karena itu, penggunaan media yang mendorong dan menimbulkan minat siswa untuk belajar sangat penting meskipun media yang digunakan bersifat media tradisional dan memiliki nilai yang sederhana. Hal ini dikarenakan, penggunaan media dalam belajar bukan dilihat dari bagaimana media itu diperoleh meski hal tersebut tetap menjadi bahan pertimbangan guru maupun sekolah, namun harus dipikirkan pula bagaimana media tersebut dapat menjadi pemicu aktivitas siswa yang lebih baik.

Berdasarkan hasil wawancara dengan para guru di SMA Negeri 3 Kota Jambi, diperoleh kesimpulan bahwa penggunaan media belum menjadi prioritas utama para guru dalam menyampaikan materi, khususnya bidang ekonomi. Selain jam dan beban mengajar para guru, mencari media yang tepat dan bervariasi akan memakan waktu dan menambah pekerjaan bagi para guru. Sehingga, papan tulis, buku literatur, dan lks sampai saat ini masih menjadi media pembelajaran yang difavoritkan oleh para guru disamping dengan tambahan biaya yang bahkan dikeluarkan dalam penggunaan media nantinya menjadi pertimbangan lain bagi para guru bidang studi maupun kepala sekolah berserta wakilnya. Dimana, nantinya mereka harus dapat menyesuaikan beban, jam, biaya, dan bobot belajar bagi para siswa disamping dengan pengajuan untuk pengadaan media yang belum pasti dan menyita tempat yang terbatas.

d. Dengan Sifat yang Unik Pada Tiap Siswa Ditambah Lagi dengan Lingkungan dan Pengalaman yang Berbeda, Sedangkan Kurikulum dan Materi Pendidikan Ditentukan Sama Untuk Setiap Siswa, Maka Guru Banyak Mengalami Kesulitan Bilamana Semuanya Itu Harus

\section{Diatasi Sendiri}

Perbedaan yang dimiliki oleh masing-masing siswa menjadi catatan tambahan bagi seorang guru dalam menyampaikan materi pembelajaran di kelas, sehingga banyak guru melaksanakan tugas dengan berbagai macam model, metode, bahkan strategi dan pendekatan terhadap siswanya. Namun, selama kegiatan belajar mengajar berlangsung pada hari ini maka belum tentu akan berakhir sama dengan pada hari berikutnya dengan materi pembelajaran yang berbeda pula. Oleh karena itu, penggunaan media yang konsisten dan tidak membuat siswa merasa bosan sangat penting untuk menjadi bahan pertimbangan seorang guru dalam memberikan materi pelajaran. 
Berdasarkan hasil wawancara dengan para guru di SMA Negeri 3 Kota Jambi, diperoleh kesimpulan bahwa penggunaan media masih dalam kegiatan belajar mengajar di kelas hanya terbatas pada buku literatur dan papan tulis kecuali pada proses belajar praktikum. Hal ini dikarenakan, selain dari penggunaan jam belajar yang harus diperhitungkan kembali, dasar acuan pembelajaran di RPP dan silabus pun harus mengalami penyesuaian agar capaian pembelajaran sejalan dengan apa yang diterapkan dalam kelas. Meskipun demikian, kurangnya pemahaman akan penggunaan media pembelajaran dan kondisi beban mengajar serta perubahan kurikulum sering menjadi faktor kegiatan pembelajaran jarang menggunakan media pembelajaran.

\section{Pembahasan}

\section{a. Strategi dan Pendekatan Melalui Penggunaan Media}

Kegiatan belajar mengajar di dalam kelas yang dilakukan oleh para guru dalam memberikan materi pelajaran kepada para siswanya membutuhkan beberapa metode, model, bahkan strategi serta pendekatan baik yang bersifat internal maupun ekternal, pribadi maupun kelompok, dan lain sebagainya dilakukan tidak lain agar capaian pembelajaran yang ditetapkan terpenuhi secara optimal. Meskipun demikian, masih banyak permasalahan juga yang terjadi apabila dilihat dari proses penyampaian materi pelajaran tersebut sehingga umpan balik yang diterima oleh para guru dari siswa sangat sulit untuk ditelaah lebih jauh. Banyak faktor yang mempengaruhi hal tersebut, dan salah satu yang dapat diambil contohnya adalah kurang tersedia media pembelajaran yang dapat digunakan oleh para guru.

Menurut hasil penelitian Prastya (2016:301), disimpulkan bahwa pemilihan media pembelajaran merupakan harga mati harus dilakukan seorang guru sebelum proses belajar mengajar dimulai, agar pembelajaran lebih menarik. Seorangguru harus mampu memilih dan menentukan jenis media apa yang tepat, supaya selaras dengan materi yang disajikan. Agar media pembelajaran sesaui dengan rencana dan tepat sasaran, maka guru harus melakukan yaitu: 1) memberi pengetahuan tentang tujuan belajar, 2) memotivasi siswa, 3) menyajikan informasi, 4) merangsang diskusi, 5) mengarahkan kegiatan siswa, 6) melaksanakan latihan dan ulangan, 7) penguatan belajar, 8) memberikan pengalaman simulasi.

Dengan demikian, dapat disimpulkan bahwa tidak hanya kegiatan dan proses pembelajaran saja yang membutuhkan strategi dan pendekatan agar siswa berhasil dalam belajarnya, akan tetapi dalam penggunaan media pembelajaran pula. Dimana, selain memudahkan guru dalam menyampaikan materi pelajaran kepada siswa, media dapat juga berfungsi sebagai 
pendorong keinginan siswa (stimuli) untuk belajar yang mana nantinya akan dapat digunakan oleh guru sebagai bahan pertimbangan akan keberhasilan siswa dalam belajar.

\section{b. Penggunaan Media Terhadap}

Kesulitan Belajar Siswa pada Mata Pelajaran Ekonomi

Tidak semua siswa memiliki keinginan, dorongan, serta minat dalam belajar meskipun dilihat dari sisi eksternal mereka atau yang dapat diberikan contoh sebagai tindakan siswa dalam mendengarkan guru saat memberikan materi pelajaran. Hal ini dikarenakan, bukan motivasi maupun minat, serta disiplin yang berperan tapi gaya belajar siswa. Hal ini juga dapat dilihat dari bagaimana siswa mengalami kesulitan baik dalam menganalisa maupun memahami materi baik yang bersifat perhitungan maupun menelaah pemahaman. Pada akhirnya, peran guru sangat dituntut untuk dapat berperan serta dalam mengatasi kesulitan belajar siswa tersebut. Dan, tentu salah satunya adalah merubah strategi dalam penyampaian materi dengan menggunakan media pembelajaran.

Cara guru melakukan suatu kegiatan pembelajaran mungkin memerlukan pendekatan dan metode yang berbeda denga pembelajaran lainya sedikitnya terdapat lima pendekatan pembelajaran yang perlu di pahami guru untuk dapat mengajar dengan baik, yaitu dengan pendekatan kompetensi, pendekatan keterampilan proses, pendekatan lingkungan, pendekatan kontekstual, dan pendekatan tematik (Mulyasa, 2008: 9596)

Menurut Musfiqon (2012:178-179) menjelaskan bahwa penerapan media dalam pembelajaran dimaksudkan agar belajar menjadi lebih efektif, lebih efisien, lebih banyak, lebih luas, lebih cepat, dan lebih bermakna bagi orang yang belajar, khususnya siswa. Untuk itu ada produk yang sengaja dibuat dan ada yang ditemukan serta dimanfaatkan dalam pembelajaran.

Dengan demikian, dapat disimpulkan bahwa dengan adanya penggunaan media pembelajaran siswa yang tidak terbiasa belajar dengan teks maupun tulisan, dapat meningkatkan pemahaman mereka dengan cara melihat tampilan video atau gambar dari media yang digunakan oleh guru tersebut contohnya. Ada beberapa siswa lebih tertarik dan mudah memahami materi dengan cara melihat gambar atau rekaman, bukan hanya foto yang ada di buku literatur, dan ada pula dengan melihat langsung tayangan yang diputar siswa memahami bagaimana proses dan cara dalam sebuah materi yang disampaikan tersebut.

\section{PENUTUP}

\section{Kesimpulan}


1. Guru memiliki berbagai strategi dan pendekatan yang digunakan dalam menyampaikan materi pelajaran yang tidak tergantung pada hanya satu media saja. Artinya, media dapat dipilih dan disesuaikan dengan kondisi baik dari guru, siswa maupun kemampuan sekolah dalam pengadaannya.

2. Kesulitan belajar siswa pada mata pelajaran ekonomi dapat diatasi dengan penggunaan berbagai media yang dapat dijadikan perantara maupun sumber bagi siswa dalam belajar. Artinya, dengan keragaman yang dimiliki siswa, media dapat menjadi sebuah mediasi dalam kegiatan pembelajaran yang diikuti.

\section{Saran}

Adapun saran-saran yang ingin peneliti sampaikan dalam penelitian ini berdasarkan data dan fakta yang ada dan terjadi dilapangan baik secara langsung maupun tidak langsung, adalah sebagai berikut:

1. Bagi kepala sekolah untuk dapat meningkatkan fasilitas bagi guru dalam menyelenggarakan penelitian di sekolah.

2. Bagi guru untuk dapat saling bekerja sama baik dalam hal penyediaan informasi maupun analisis data yang dibutuhkan dalam membuat karya ilmiah.

3. Penelitian ini diharapkan dapat menjadi acuan bagi peneliti lain yang melakukan penelitian sejenis untuk menyempurnakan hasil penelitian ini, selain dari dimensi maupun indikator yang telah digunakan untuk lebih mengetahui gejala maupun fenomena lain yang ada terhadap karya ilmiah atau penelitian guru.

\section{DAFTAR PUSTAKA}

Aunurahman. (2016) Belajar dan pembelajaran. Bandung: CV. Alfabeta.

Hamdani M.A. (2011) Strategi Belajar Mengajar. Bandung: Pustaka Setia.

Moleong, Lexy J. (2017) Metodologi Penelitian Kualitatif, Cet. Ke-36. Bandung: PT. Remaja Rosdakarya.

E. Mulyasa. (2008). Menjadi Guru Profesional Menciptakan Pembelajaran Kreatif dan Menyenangkan. Bandung : PT. Remaja Rosdakarya.

Musfiqon, HM. (2012) Pengembangan Media dan Sumber Pembelajaran. Jakarta: PT. Prestasi Pustakaraya.

Prastya, Agus. (2016) Strategi Pemilihan Media Pembelajaran Bagi Seorang Guru. Prosiding Temu Ilmiah Nasional Guru (TING) VIII. Hal: 294-302.

Sadiman, Arief. S., Rahardjo, R., Haryono, Anung., dan Rahardjito. (2012) Media Pendidikan; Pengertian, Pengembangan, dan Pemanfaatannya. Jakarta: PT. RajaGrafindo Persada. 